\title{
LINGUSTIC AND CULTURAL ASPECTS IN ANIMISTIC IDIOMS DEFYING PERSONAL CHARACTER TRAITS IN ENGLISH AND UKRAINIAN
}

Єловська Ю. В. Лінгвокультурний аспект вивчення фразеологізмів на позначення рис характеру людини в англійській та українській мовах.

У статті розкрито лінгвокультурний компонент вивчення фразеологізмів на позначення рис характеру людини в англійській та українській мовах. Проаналізовано особливості пошуку еквівалентних сполучень у процесі перекладу фразеологічних відповідників у різних мовах на прикладі сполучень із зоокомпонентом. Проілюстровано, що фразеологізми мають національноспецифічні ознаки, притаманні кожній мові окремо і $\epsilon$ відображенням національно-культурної самобутності.

Ключові слова: фразеологізм, національно-культурна специфіка, лінгвокультура, риси характеру, зоонім. 
Еловская Ю. В. Лингвокультурный аспект изучения фразеологизмов, обозначающих черты характера человека в английском и украинском языках.

В статье раскрывается роль лингвокультурного компонента в изучении фразеологизмов, обозначающих черты характера человека в английском и украинском языках. Анализируются особенности поиска эквивалентных сочетаний в процессе перевода фразеологических единиц в разных языках на примере конструкций с зоокомпонентом. Иллюстративно доказано, что фразеологическим единицам свойственны национально-специфические признаки, характерные конкретному языку, которые отражают национально-культурную самобытность.

Ключевые слова: фразеологизм, национально-культурная специфика, лингвокультура, черты характера, зооним.

Yelovska Yu. V. Linguistic and cultural aspects in animistic idioms defying personal character traits in English and Ukrainian.

The problem of studying national and ethnic-cultural components is an actual trend in contemporary linguistic studies, since linguistic elements manifest distinct national marking. The idea of language and culture interconnection belongs primarily to William von Humboldt. The language units can be treated as the specific treasury that preserves national identity of a certain language community. O. Potebnya expressed his own original vision of idioms, which he considered as a small version of the "whole world". Having symbolic correlation with cultural signs, experience and behaviour stereotypes idioms represent universal ideas common to different language systems. Nevertheless there are also peculiar images belonging only to certain language groups and its interpretation demands deeper language and cultural code analysis.

This research mainly focuses on studying idioms expressing the traits of character and behavioral habits through the animistic phraseological structures while bilingual teaching of English and Ukrainian in particular. The diversity of idioms with animistic components in their structure is rather various and can be hardly illustrated in one research. That is why the main attention of this study is paid to idioms with animistic components representing the following images: domestic animals and insects.

The first group includes set expressions, which are distinguished according to the presence in their structure such words as $a$ dog, a sheep, a hen. Illustration analysis shows that these animistic components are represented in both languages. Furthermore some idiomatic constructions demonstrate similar meaning and structure. The second group comprises comparatively smaller number of samples. It contains idioms defying rather emotional state of a person and his / her behavior rather personal character trait itself. The analysis of English and Ukrainian illustrations demonstrates the low correspondence of samples in both languages. Despite the fact that the world vision in both nations contains similar ideas about emotional state of a person and his / her behavior, its linguistic representation is totally different.

(c) Yu. V. Yelovska, 2018. 
The results of practical analysis vividly confirm the idea of national and cultural marking revealed in set expressions for both languages. It also shows the necessity of profound investigating national and cultural symbols while studying language phraseological and paremian heritage. These observations might help in highlighting more complicated world perception characteristics in English and Ukrainian.

Key words: set expression, national and cultural peculiarities, language community, traits of character, animistic component.

Any language appears to represent the mentality of one particular ethnic group. It becomes a powerful source of spiritual code and the reflection of everything that exists in a certain culture. The problem of studying national and ethnic-cultural components is an actual trend in contemporary linguistic studies, since linguistic elements manifest distinct national marking.

The idea of language and culture interconnection belongs primarily to William von Humboldt. According to the philosopher language illustrates culture, as well as expresses the individuality of a speaker. Supporting these statements S. Gurbanska claims that language functions as a specific indicator of an ethnic group, aimed to organize it [1, p. 34]. Taking into account these ideas one can come to conclusion that language units can be treated as the specific treasury that preserves national identity of a certain language community. More specified forms and constructions such as unique idiomatic expressions (further idioms) that contain peculiar senses and cultural codes allow the researcher to reveal national identity and ethnic marking of a certain language group or nation. O. Potebnya expressed his own original vision of idioms, which he considered as a small version of the "whole world". In other words, an idiom could be defined as a shortened piece of reality fixed in words having its unique symbolic meaning, covering complex notions, communicative situations etc [3].

Hence we can assume that idioms, set expressions and proverbs are essential in studying the peculiarities of national character in a certain language community and personal character traits in particular. This research focuses on cultural and national connotations of paremian 
and phraseological units, as well as investigating their meaning in the cultural interpretation and national worldview. The aim of the study is to disclosure the specific ways of introducing personal character traits common to a certain language group (English and Ukrainian); especially revealed in the idioms with animistic components.

Uncovering cultural codes hidden in set expression of a certain language community is one of the difficult tasks that arises in front of the researcher. Even more complicated problems appear while investigating cross-cultural language units, especially in terms of intercultural communication. The most common difficulties in bilingual teaching are connected with the correctness and appropriateness of idiom usage in speaking. Having symbolic correlation with cultural signs, experience and behaviour stereotypes idioms represent universal ideas common to different language systems. Nevertheless there are also peculiar images belonging only to certain language groups and its interpretation demands deeper language and cultural code analysis.

As mentioned by J. Lagodenko various languages demonstrate through the idiomatic units not only the different cultural notions and reality items but mostly specific world visions typical for a certain language community. Though there are no doubts that some ideas come crossed in many cultures [2, p. 248-252].

This research mainly focuses on studying idioms expressing the traits of character and behavioral habits through the animistic phraseological structures while bilingual teaching of English and Ukrainian in particular. J. Szerszunowicz has already noted that the key point in analyzing and comparing the set expressions of two or more languages is connected with searching their accurate equivalents. She differentiates correspondingly four main stages that comprise: 1) idiom identification in the source and target languages; 2) analyzing its meaning and composing a paraphrase in the source language; 3) translating the made up paraphrase; 4) finding the corresponding substitute in the target language [4, p. 301-305].

We assume that this technique can be used in case with totally 
common universal notions represented in both languages. Let us move on the national character traits peculiar to the English and Ukrainian language communities. No doubt that every nation has in its heritage idioms cherishing positive personality characteristics and condemning the opposite ones. Ethnic and national identity can be traced through the images and symbols which embody this or that meaning.

In many languages, personal character traits are demonstrated through the animistic images. The basis of zoomorphic idiom vocabulary is formed by attributed animistic qualities produced by the creative folk thinking. It should be noted that the same animals can receive both similar or different associations in the conscience of various language communities, taking correspondingly different evaluation and importance in the national world view.

The diversity of idioms with animistic components in their structure is rather various and can be hardly illustrated in one research. That is why the main attention of this study is paid to idioms with animistic components representing the following images: domestic animals and insects.

The first group includes set expressions, which are distinguished according to the presence in their structure such words as adog, a sheep, a hen. Illustration analysis shows that these animistic components are represented in both languages. Furthermore some idiomatic constructions demonstrate similar meaning and structure. Let us consider some of them.

For instance, phraseological units with a dog-component demonstrate alike connotations. Perhaps it can be explained by mutual understanding and evaluation of both nations to this animal. Dogs are perceived as the first domesticated animals, and can refer to a wide variety of symbolic meanings, from loyalty ("man's best friend"), to abuse ("treated like a dog"), exhaustion ("dog-tired") or tenacity ("doggedness").

It should be mentioned that the image of a dog in both nations reveals its double nature. On the one hand a dog is considered as the 
symbol of a loyal friend and a true defender. On the other hand it embodies the evil, dangerous and traitor characteristics. However, both in English and Ukrainian we can hardly find enough samples of positive connotation. As for the negative one a great diversity of samples can be met. For example, the following samples demonstrate the full equivalence of meaning and structure and can be easily translated: a dangerous, sly and deceptive person: slydump dog (1, p. 219) - потайний собака (3, p. 838); a dirty dog - злий / скажений як собака (5, p. 557); Dog shall die a dog's death (4, p. 363$)$ - Собаиі собача смерть (6, p. 326).

In the same time some positive meaning characterizing a person or his / her behaviour bears no resemblance in structure and can hardly be found. For instance, English idioms a clever $\operatorname{dog}$ (1, p. 220) identifying a very clever person or a top $\operatorname{dog}(1$, p. 220) describing person's high social status have no similar equivalent in Ukrainian. As well as Ukrainian set expressions вірний як пес (5, p. 557), naming a loyal friend or битий собака $(5$, p. 838$)$ characterizing an experienced man have no direct translation. Such cases are quite often in the translation procedure. Thus the necessity of deeper penetrating into the national peculiarities of word perceptions and national symbols is of high importance in terms of bilingual teaching. Furthermore it demands additional context for the accurate idiom decoding.

Almost full equivalent correspondence is demonstrated by the samples with the sheep-components. Both nations comprehend this animal as the bearer of light mind, stupidity and easy trust. These characteristics are revealed in the following phraseological units: lost sheер (1, p. 674) - заблукана вівия (3, p. 113); black sheep (1, p. 674) - паршива вівия (6, p. 283); One scabbed sheep infects the whole rock sheep among wolves (1, p. 675) - Одна паршива овечка усю отару поганить. Париива вівия все стадо спаскудить (6, р. 283).

Quite short variety of similar idioms can be found with the hencomponent in English and Ukrainian. Moreover, it should be noted that in English variants $a$ hen is associated mostly with fussy behaviour. A 
person who looks out for the welfare of others to a fussy, intrusive and overprotective degree is often called: a mother hen (2, p. 192) - як квочка (3, p. 367). Absurdly fussy and overanxious behaviour is represented also by such idioms like a hen with one chick (or chicken) (2, p. 142) - носиться як курка з яицем (3, p. 406). Analysis of Ukrainian phraseological units shows a greater diversity of samples describing various person's characteristics usually with sarcastic or humorous connotation which have no similar equivalents in English: a weak eyed-person: сліпа курка (3, p. 406); a miserable, pathetic and weak-willed person: мокра курка (3, p. 406); a stupid narrow-minded person: куряча голова / мозок $(3$, p. 406); in a messy inaccurate way: як курка лапою $(3$, p. 406). Such peculiarity can be explained by special national world comprehending, constant nature observations and strong agriculture ties that influence greatly on Ukrainian mentality.

The second group comprises comparatively smaller number of samples. It contains idioms defying rather emotional state of a person and his / her behavior rather personal character traits itself. However, emotions and behavioral patterns are the system components that build up the person's character and can not be neglected. The analysis of English and Ukrainian illustrations demonstrates the low correspondence of samples in both languages. Despite the fact that the world vision in both nations contains similar ideas about emotional state of a person and his / her behavior, its linguistic representation is totally unlike.

For example, the illustrations with insect-components describing person's anxiety in English hardly correspond to Ukrainian translations. Furthermore insect symbols bear totally different meanings. An excited nervous person with an obsessive preoccupation with something is described by the following idioms: ants in pants (2, p. 7); a bee in a bonnet (2, p. 20); butterflies in stomach (2, p. 43).

The same insects in Ukrainian mentality represent totally different perspectives. For instance, ants are associated with hard work and welfare $(5$, p. 379$)$. Set expressions with this component mostly 
denote shivering or trembling signs caused by fearful state of a person: мурашки бігають / повзуть (3, р. 512.).

A bee is a special symbol in the Ukrainian worldview. The main characteristics connected with this symbol include welfare, hard and fare work. It is considered to be the "God's bird" or the "God's insect" (5, p. 30), and it has no negative connotations. The only slight resemblance that can be traced between two languages is the idiom busy as a bee (2, p. 38) - заклопотана бджілка (5, p. 42); which marks a very busy and hard-working person.

Butterfly-component is used in the idioms representing whether funny behaviour usually to emphasize childish attitude to things: ловити білі метелики (6, p. 283) or describing permanent loss of consciousness due to faint or drunken state: метелики в очах замигтіли (3, p. 484).

In our view, the results of practical analysis vividly confirm the idea of national and cultural marking revealed in set expressions of both languages. It also shows the necessity of profound investigating national and cultural symbols while studying language phraseological and paremian heritage. These observations might help in highlighting more complicated world perception characteristics in English and Ukrainian using the proposed translation technique. Further work will be concentrated on idiom grammar structuring and its correlation in different languages, as well as the peculiarities of clear or dimmed meaning motivation and symbol equivalence in these set expressions.

\section{References}

1. Гурбанська С. О. Лінгвістичний та культурний аспект вивчення інтертекстуальних фразеологізмів/ С. О. Гурбанська // Філологічні студії : Науковий вісник Криворізького державного пед. ун-ту : зб. наук. праць. - Вип. 8. - Кривий Ріг : ТОВ «ОКТАН-ПРИНТ», 2012. - С. 31-37.

2. Потебня А. А. Из записок по теории словесности/ А. А. Потебня. Харьков, 1905. - 652 с.

3. Lagodenko J. Semantic Interpretation of Idioms: Cross-linguistic Approaches / J. Lagodenko // Research on Phraseology Across Continents. - Volume Two. - 2013. P. 248-259. 
4. Szerszunowicz J. Phraseological Gaps as a Translation Problem / J. Szerszunowicz // Research on Phraseology Across Continents. - Volume Two. 2013. - P. 299-318.

\section{Illustration sources}

1. Жайворонок В. В. Знаки української етнокультури : [словник-довідник] / В. В. Жайворонок. - К. : Довіра, 2006. - 703 с.

2. Кунин А. В. Англо-русский фразеологический словарь / А. В. Кунин. - М. : Русский язык, 1984. - 944 с.

3. Русско-английский словарь пословиц и поговорок / [под ред. А. Маргулис, А. Холодная]. - Джефферсон, Северная Каролина, Лондон : McFarland and Company, Inc., Publishers, 1974. - 487 c.

4. Словник фразеологізмів української мови / Уклад. В. М. Білоноженко та ін. - К. : Наукова думка, 2003. - 1104 с.

5. Українські прислів'я і приказки / Уклад. М. Номис. - К. : Либідь, 1993. $768 \mathrm{c}$.

6. Oxford Dictionary of Idioms / [ed. J. Siefring]. - New York : Oxford Univerity Press, 2004. -340 p.

Стаття надійшла до редакиії 06.03.2018 p. 